\title{
“A Megesalt Férj" or Cunningly Lingual Wives in Hungarian Ballad Tradition
}

\author{
Louise O. Vasvári \\ Stony Brook University \\ New York, USA
}

\section{Abstract}

In this report I shall study one widely circulating European ballad tradition concerning wifely infidelity, to illustrate that although details among versions are temporally and culturally variable, they all belong to one narrative deep structure having to do with "cunningly lingual" wives and cuckolded husbands. These adulterous wives are a subcategory of the persistent antifeminist stereotype of the "unruly woman," whose too active mouth, whether its voraciousness, garrulousness, or verbal cunning, implies bodily misrule, a topsy-turvy displacement of a woman's even more fearful orifice, the vagina. I will mention noteworthy highlights from several ballad traditions, but I will concentrate on the Hungarian corpus.

Through a gender-conscious reading, I will show that these retold tales that pretend to be about conjugal relations are merely another variant of misogynist male discourse on women, where the "misogyny reveals far more about masculinity and male views of the feminine than about real women" [Gaunt 1995: 71]. In addition, hegemonic masculinist interpretations, including by scholars, have been complicit in a directed reading away from the misogyny.

The earliest known variants of the ballad I shall discuss survive in two traditional medieval Spanish ballads, known also in hundreds of modern oral variants. Beyond Hispanic tradition, versions also appear in many other languages, including French, Italian, in South Slavic languages, and even in Yiddish, with the most widespread variants in Anglo-American tradition [for a detailed analysis of these traditions, see Vasvári 2008].

All the ballads in the tradition narrate how a husband returns home unexpectedly and surprises his wife with her lover. The lover's presence is gradually revealed through a series of tell-tale clues-typically a horse, a sword, a hat, and perhaps physical evidence, such as his clothes, or, finally, even the sight of his moustache in the bed. The narrative core of 
the ballad is a reiterative "testing dialogue," in which the husband questions his wife about all the signs of her infidelity and through a smokescreen of cunning semiotic ruses she attempts to manipulate all the signs of her guilt by relocating them in a new context created by her women's speech. She might claim, for example, that the saddled horse standing outside is a gift from her father for the husband, or, more ludicrously, that it is the cow that the maid left there; that the lover's blue dolman on the bed is actually a mildewed bedspread; or, in an obscene variant, even that the lover's genitalia are parsnips or perhaps beets! While the structure (but not the details) of the dramatic testing dialogue occur in almost all versions of the ballad, there are a variety of possible endings, ranging from the sadistic to the merely punitive, to the ambiguous and the comic, with the latter ending with the wife's linguistic and sexual victory-a carnivalesque temporary suspension or reversal of normal rules of patriarchal culture.

It is the Hispanic variants of The Adulterous Wife that have been most widely studied, with some earlier critics claiming that since the common origin of the plot is from a medieval comic fabliau, the originality of the Spanish version resides in having given the theme a morally superior tragic orientation, where the wife gets her deserved punishment. In fact, however, although the two extant oldest versions end with the wife's death, among the hundreds of modern versions there are also many humorous ones. And, as we shall see, Hungarian tradition contains far more violently sadistic versions than any known even in earlier Hispanic tradition.

Although ballad collection in Hungary started very late, with the first printed collections dating, not coincidentally, from the period of the war of independence in 1846-48, it is likely that some of the earliest themes (such as that of the building sacrifice) go back to ancient traditions [Balassa and Ortutay 1984: 515, Dundes 1996]. Vargyas conjectures, probably without adequate justification, that the Hungarian version of the cunningly lingual wives ballad was a late addition to the tradition, based on a German ballad which circulated in the eighteenth century. However, Armistead [2000: 70-71] has cogently argued for the importance in the Hungarian repertoire of the region's interaction with neighboring traditions, which suggests that the ballad could have just as well reached Hungary through oral means.

The Hungarian ballad called "Bárcsai"- after the lover's name, is known only in Transylvania, in five versions and one fragment [English versions in Leader 232-39; Vargyas 1983:11-14; Balassa and Ortutáy 
1984: 531-32]. The fifty-line Bárcsai begins in direct dialogue, with the deceitful wife urging the husband to go to Kolozsvár to bring her back some batiste from her father's house, when their son interrupts to warn the father not to leave because the mother loves Bárcsai: ne menj apám, ne menj, aj ne menj házrol ki: Anyámasszony bizony Bárcsait szereti [Do not go, father, do not go, aye, do not leave the house, / for mother is in love with Barcsai]. This beginning is unusual in that the wife does not merely use the opportunity of her husband's absence but actively plots his departure, and even more unusual is the active voice of the son because normally the mention of children in adultery stories is avoided, probably as their presence would be too suggestive that that child may not be the father's, either.

Heeding his son's words, the husband decides to turn back halfway. On his return he asks his wife to open the door, and there ensues a ritual series of requests and delaying tactics where she asks him, in turn, to wait until she puts on her skirt, her apron, her newly-soled boots, and her scarf. Here the ritual questions are not a testing dialogue about the signs of the other man, as in most of the variants, but rather a catalogue of the (presumably undressed) wife's reverse striptease. Vargyas claims that there are no known analogues to this ballad, but this scene actually illustrates a clear interaction with other traditions, as, for example a Catalan version, where another adulterous wife who hears a knock says she is ready to open for her lover but needs time to put on her clothes and shoes if it is her husband [Vasvári 1999: 77, n. 4].

Losing patience, the husband finally breaks down the door and demands the key to the chest in which the lover is hiding. The wife claims to have lost the key in the garden, but he kicks the chest open, finds the lover, and cuts off his head. The scene is familiar from fabliau tradition with the sexual suggestiveness of a phallic key, a folk symbol for the male organ (as, for example, in the jazz lyric, You've got the right key but the wrong keyhole), and the lover hiding in the chest, in turn, an image suggestive of the woman's sexual organ. Nevertheless, here it is really the lengthy dénouement with the husband's sadistic verbal and physical revenge that is most important. He offers his wife three choices of death: to cut off her head, to sweep the house with her hair, or to let her sit up till morning bearing candles to entertain seven guests:

Három halál közül melyiket választod:

Vaj föbe löjjelek, vaj fejedet veghem,

Vaj hét asztal vendégnek vigon gyertyát tartasz"

FOLKLORICA 2009, Vol. XIV 
[Do you hear, wife, do you hear, wife, do you hear?

Which one will you choose of the three deaths?"

Have your choice now: shall I take your head?

Or shall I sweep the house with your silk hair?

Or would you prefer to sit up till morn,

And bear candles to the entertainment of seven boards of guests?]

(The English translation in Leader 1967 I follow takes six lines to reproduce the three of the Hungarian.)

The wife naturally falls into the trap of choosing the third option, which is in actuality the most sadistic one. The husband then orders the servants to roll her up head to toe in oilcloth covered in pitch and the batiste that was "given free" by his father-in-law (an illogical detail, since having turned back halfway, he would not have been able to bring home the cloth), in effect making a candle out of her. In another version he has this done not by the servant but twelve young men, who are then to feast all night, with Gypsy music playing, as she burns to death. This very sadistic version shows that the husband's performance of heterosexual masculinity-here the salvaging of his honor-has to be acted out in a disciplinary program, whereby men need to show that they can master their wives in front of other men in a homosocial bonding situation, in this case specifically with young unmarried men, who are to learn from it how to deal with insubordinate women [for a similar case see my analysis of Dec 9.9, 2004: 313-336].

Alongside this sadistic Bárcsai, there exist comic adultery ballads in Hungarian, where it is less the craftiness of the woman that is emphasized than the stupidity of the henpecked and cuckolded husband. In a one-hundred-verse ballad collected by Béla Bartók from a twentysix-year-old woman in 1918, A megcsalt férj [The Deceived Husband] [Vargyas 1976: 936-38], the husband is so aware of his plight that as he goes deeper and deeper into the house, from the barn, to the kitchen, hall, the main room, and the bedroom, he keeps on repeating: Elhagyatott, megcsalhatott / férj vagyok mindég [Am I not the silliest, most deceived husband that ever was?]. The couple exchange incongruously endearing vocatives during their interchange, he beginning each question with the ironic [kérdem] édes kedves feleségem '[[I ask you] my dear sweet wife]' and she, in turn, replying mi baj van, angyalom [what's wrong my angel], a detail probably influenced by a German version, which has herzliches Weibchen and mein Schätzchen, respectively.

Although F. W. Meyer translated from English in 1790 what he called "The Tenant Farmer's Return" that he called a Bänkersängerlied 'street ballad' in German, the Hungarian version has enough difference 
from that German translation to show that it has clearly entered oral tradition and has been influenced by other variants. For example, in the German version the boots are beer tankards, the swords are spits to roast larks, and the jackets are tablecloths. As in the English predecessor of the ballad, the husband sees the following as he goes deeper and deeper into his house, from barn to kitchen, to hall, to room, to bedroom: three horses, which his wife calls milk cows her mother sent, three boots, which she calls beer tankards, three swords which she calls spits for larks (Lerchenspitze), and three jackets which she calls tablecloths, until he gets to the bedroom, and in bed he sees three knights, whom his wife calls milkmaids and then comes the punch line, uttered by the husband: "I've never seen milkmaids with moustaches (Zwickelbarte)." In the Hungarian version the testing dialogue proceeds in five parts. The husband asks, in turn, whose are the boots, the swords (in the plural), the pair of soldiers' hats, the coats, and he gets the replies that they are milk jugs, swords, kitchen knives, milk pots, and the servant girl's mildewed dress. The wife's replies are not merely lies but transparently ludicrous reinterpretations of language, attempting to deceive the husband both verbally and visually in order to convince him, literally, not to believe his eyes. Finally, he asks, who are the pair of soldiers on his bed, and she replies it is her grandmother's maid sweeping the room, to which he snaps back with what should be the punch line: szolgálonak pörge bajszát 'Aj, ki látott már [whoever saw maids with red moustaches].

At this point, the comical version should end, or at best continue with an appropriate revenge, as in the German version, where the husband beats his wife, claiming that the blows were caresses sent by her mother, which Vargyas deemed to be a very "felicitous ending," but which I have called elsewhere "bawdy battering," that is, where a wife's beating is considered the height of humor because it is embedded in a comic text [Vasvári 2004: 313-336]. However, here the ending suddenly turns brutal, with the husband declaring that he will hold a ball and behind the door there awaits a knotted rope and a big cudgel, an ending that is clearly a contamination from Bárcsai. The knotted rope also recalls the Hungarian proverb: a kötél ásztatva, az asszony verve jó [a rope is good when wet and a woman when beaten]. Nor can this sadistic ending be simply a confused version recounted by one person because it appears elsewhere, as well. This is a clear indication that even if this comic version is a translation from the German, the deep structure adultery plot is so primary that it is possible to fuse such disparate treatments. 
In living twentieth-century Hungarian and Romani tradition there are a number of comic songs about adulterous wives which are reduced only to the bare-bones testing dialogue, that I offer here in translation. The first is translated from the Romani [Csikó 1977; Csenki and Csenki 1980] and the second was collected by Bartók and Kodály [1979: 454]. We should not be surprised by the image of Puss in Boots in the first verse if we consider its potential erotic suggestiveness:

\author{
Az Ablaknál ki járt éppen? \\ Mondd meg nekem, feleségem! \\ Ablakom alatt ki járt ma? \\ Csak a szomszédok macskája, \\ Szomszédunké ottan hátra, \\ Szomszédunké ottan hátra. \\ De macskának nincs kalapja, \\ A macskának nincs kalapja, \\ Se a lábán nincsen csizma, \\ Se a lábán nincsen csizma. \\ Ej, dehogy a macska volt az, \\ A szeretőd maga volt az.
}

[Who just walked by under the window? / Tell me, my wife! / Who walked under the window today? / Just the neighbor's cat, / our neighbor's back there, / our neighbor's back there. // But cats don't wear a hat, / cats don't wear a hat, / and they don't wear boots either,' and don't wear boots either. / No, it certainly wasn't the cat but it was your lover himself. ]

Sári lányom, ki járt itt, ki járt itt,/ kinek a nagy pipaszára maradt itt? Gépész, uram, jára itt, jára itt. / Annak a nagy pipaszára maradt itt. Hát az ágyat mi lölte, mi lölte,/ Mért van ugy összegyürve, de gyürve? Cica fogott egeret, egeret, / Jatszott vele eleget, eleget.

Hát a hasad mi lölte, mi lölte, / Miert van igy megpüffedve, püffedve? Túrot ettem fikhagymát, fikhagymát, / Attol püffedt ekkorát, ekkorát.

[My dear Sarah, who was here, who was here, / whose big pipe stem got left behind? / A mechanic was here, my husband, / it was his big pipe stem that got left behind. // And the bed, who poked at it, who poked at it? / Why is it wrinkled, all wrinkled?/ The kitten caught a mouse, a mouse / and played with it a lot, a lot./ And what poked at your stomach, what poked it? / Why is it so puffed up, puffed up? / I ate farm cheese with garlic, / and that's why it puffed up so much, so much.]

In the nineteenth century there were also a number of songs collected in French and Italian dialects that had comic dénouements. However, by far the most widespread comic versions are in Anglophone 
tradition in two main variants, Our Goodman and the Merry Cuckold, where the song is a folk classic, perhaps the most popular ballad in oral tradition. Over four hundred versions have been collected in British and American tradition, including many from hillbilly recordings, and as far away as New Zealand and even India. Because of its erotic nature Francis James Child only exceptionally allowed it into his magnum collection [Child 1965: V. 274]. Our Goodman is better classified as a joke ballad, a narration of a humorous event working toward the surprise punch line, so that if the punch line is omitted or ruined the story is ruined, which explains why some Spanish and Hungarian versions with the violent endings grafted on cannot work except for those who find the wife battering hilarious. In a broader sense Our Goodman belongs to jokelore, a liminal popular oral discourse, the vast majority of whose manifestations are male-to-male, commenting on gender relations and aimed at relieving unfulfilled or failed sexual desire, with blame always placed on the woman as, alternately, promiscuous or frigid [Dreitser 1999].

In Our Goodman the husband comes home drunk every night, a detail omitted in the The Merry Cuckold, where, on the other hand, the extra ludicrousness is provided by the husband coming home and finding not one but three men in his bed. Both proceed with versions of the expected testing dialogue, where the wife gives absurd replies, claiming that the horse is a pig, or that the three horses are milking cows, the sword[s] are a porridge-spurtle or roasting spits, the wig is a hen, or, alternately, that the three cloaks are bedspreads, the boots, pudding bags, the three pairs of breeches, petticoats, the three hats, skimming dishes, the head of the lover in bed, a mush melon, or the three lovers in bed, milk-maids.

Punch lines include: Godzounds! Milking maids with beards on! The like was never known! or, in another version, But whiskers on a baby's face / I never saw before, or the somewhat snappier I've traveled this wide world over, a hundred miles or more, / but whiskers on a mush melon I never did see before (with the Yiddish variant, But whiskers on a cabbage head I never saw before). In fact, in many cases informants were handicapped by modesty and would not reveal much more obscene versions they knew, and in other cases collectors would not write down such versions [on the bowdlerization and expurgation of sexual folklore, see Goldstein 1967: 374-386]. Fortunately we have a few of these collected in Eugene Vance's collection of "unprintable folk songs," which give a flavor of some of those bowdlerized punch lines, as in the 
following [53-57; see also Goldstein 1967: 376]: But a pecker on a hired girl/ I never seen before; But ballyx on a rolling pin/I never seen before, or to the question: Whose prick is in the cunt where mine had ought to $b e$ ? And the following answer:

You old fool, you blind fool, an' can't you plainly see

It's nothin' but a parsnip my granny sent to me?-

Well, it's miles I have traveled, this wide world all o'er,

But ballyx on a parsnip I never saw before.

In the tamer versions the lover is metonymically represented by his beard of whiskers, which is, along with face, forehead, eyes, and mouth, the public part of his face which concentrates social identity, in the obscene versions he is metonymically reduced to his private parts, which normally are concealed. Worse, these sex organs are described as parsnips, or in another version, pickled beets, what I have elsewhere dubbed "vegetal-genital onomastics."

As I was preparing this study I happened to receive an e-mail version of jokelore in Hungarian that in its deep structure clearly belonged to this same tradition, but with a difference, for here for the first time we get a husband who gives more than ample cause for his wife's adultery, and it is she who gets the appropriate punch line, as well. Could this finally be a subversive version in oral jokelore of our tired retold tale? I offer here a translation of the Hungarian version I heard, but I assume that English versions circulate, as well:

A wife says to her husband in a dissatisfied voice:

-- Géza! The light isn't working.

-- What am I, an electrician?

The next day she says again.

-- Géza, the faucet is leaking.

-- What am I, a plumber?

The third day.

-- Géza! The shelf fell off.

-- What am I, a carpenter?

The next day the husband steps into the house, and the lights are lit, the faucet doesn't drip, even the shelf is in its place. 
-- Who fixed these?

-- The neighbor came over and he said he'd fix everything if I bake him a cake or I go to bed with him.

-- And what did you do?

-- What am I, a baker?

In a continuation of the spirit of the medieval discourse on women, where the earliest versions of these tales originated, some scholars today are still capable of misreading misogynist texts as if they were guidebooks for morality. Wolfgang Spiewok [1994: xii] raises the question why might it be that so many German novelle ridicule cuckolds, and why in a society where a husband would have had the legal right to kill both the wife and lover, they escape without punishment. He concludes that these stories were a warning to married men, and that, after all, these "cheerful and amusing" stories can be useful to the modern Leser '[male] reader' who, if he finds himself in the role of the husband, will be able to learn some lessons, which today are still full of life and worthy of being read.

In contrast to such masculinist misreading, in a perceptive study Rüdiger Schnell [1998: 776-82] discusses how the most important boundary in discourses on the sexes is not between positive and negative representations of women, as both are the result of the same androcentric perspective aimed at the domestication and repression of women. What is more important is the distinction between the discourse on woman and the discourse on marriage, where in the former, images of women are constructed without any critical reflection about men, as in all but the very last jokelore example of my study. In contrast, the discourse on marriage discusses the difficulties of married life and presents a more differentiated view of women.

\section{BIBLIOGRAPHY}

Armistead, Samuel. G. 2000. "Ballad" and "Hungary" in Medieval Folklore. An Encyclopedia of Myths, Legends, Tales, Beliefs and Customs. C. Lindahl et al eds. Santa Barbara, CA. ABC-CLIO, 61$2,70-1$.

Balassa, Iván and Zoltán Ortutáy. 1984. Hungarian Ethnography and Folklore. Budapest: Korvina Kiadó.

Bartók, Béla. 1979 [1931]. Hungarian Folk Music. trans. M. D. Calvocorressi. Westport, CT: Hyperion Press. 
Bartók, Béla and Zoltan Kodály, (eds.). 1973. A magyar népzene tára [Collection of Hungarian Folkmusic]. I.1. Budapest: Akadémiai Kiadó,.

Child, Frances James, (ed.). 1965 [1882-98]. The English and Scottish Popular Ballads. New York, NY: Cooper Square Publishers.

Csenki, Imre and Sándor Csenki. 1980. Cigány népballadák és keservesek [Gypsy Folk Ballads and Laments]. Budapest: Európa Könyvkiadó.

Csikó, Z. 1977. Magyarországi cigány népköltészet [Hungarian Gypsy Folk Poetry]. Budapest: Europa Könyvkiadó.

Dundes, Alan. 1996. The Walled-Up Wife: A Casebook. Madison: University of Wisconsin Press.

Dreitser, Emil A. 1999. Making War; Not Love. Gender and Sexuality in Russian Humor. New York, NY: St. Martin's Press.

Gaunt, Simon. 1995. Gender and Genre in Medieval French Literature. Cambridge: Cambridge University Press.

Goldstein, Kenneth S. 1967. "Bowdlerization and Expurgation: Academic or Folk," Journal of American Folklore 80: 374-386.

Leader, Ninon. 1967. Hungarian Classical Ballads and their Folklore. Cambridge: Cambridge University Press.

Schnell, Rüdiger. 1998. "The Discourse on Marriage in the Middle Ages." Speculum 73(7): 771-86.

Spiewok, Wolfgang. 1994. Deutsche Novellen des Mittelalters, I. Griefswald: Reineke Verlag.

Randolph, Vance. 1992. Roll Me in Your Arm: Unprintable Ozark Folksongs and Folklore. I. Fayeteville: University of Arkansas Press.

Vargyas, Lajos (ed.) 1976. A magyar népballáda és Europa [The Hungarian Folk Ballad and Europe] II. Budapest: Zenekiadó.

Vargyas, Lajos, (ed.). 1979. Balládas könyv [The Book of Ballads]. Budapest: Zenemükiadó.

Vargyas, Lajos, (ed.). 1983. Hungarian Ballads and the European Ballad Tradition. 2 vols. Budapest: Akadémiai Kiadó.

Vasvári, Louise O. 1988. "Vegetal-Genital Onomastics in the Libro de Buen Amor." Romance Philology 42: 1-29.

Vasvári, Louise O. 1999. The Heterotextual Body of the Mora Morilla. London: Queen Mary and Westfield College.

Vasvári, Louise O. 2004. "Buon cavallo e mal cavallo vuole sprone, e buona femina e mala femina vuol bastone': Medieval Cultural Fictions of Wife Battering." in Love, Marriage, and Transgression 
Cunningly Lingual Wives in Hungarian Ballad Tradition 153

in Medieval and Early Modern Literature. Albrecht Classen, ed. Tempe, AZ: Arizona Center for Medieval and Renaissance Studies, 313-336.

Vasvári, Louise O. 2008. "Cunningly Lingual Wives in European Ballad Tradition." in Spain's Multicultural Legacies. Adrienne Martin and Cristina Martinez Carazo, eds. Juan de la Cuesta, 297-314. 